\title{
Greek Senior High School Students' Perceptions about Science and the Scientific Community as These Appear in the Mass Media
}

\author{
Evangelia Mavrikaki, Ph.D. (Corresponding author) \\ Assistant professor of Biology and Health Education \\ Department of Primary Education \\ University of Athens \\ E-mail: emavrikaki@primedu.uoa.gr
}

Charis Antonatou, M.Ed.

Biology Teacher

E-maill: charisanton@gmail.com

Argyrios Kyridis, Ph.D.

Professor of Sociology of Education

Department of Nursery Education

Aristotle university of Thessaloniki

E-mail: akiridis@nured.auth.gr

Received: August 20, 2012 Accepted: September 21, 2012 Published: November 1, 2012

doi:10.5296/jse.v2i4.2270

URL: http://dx.doi.org/10.5296/jse.v2i4.2270

\begin{abstract}
This research aimed on revealing Greek senior high school students' perceptions about the role of science and scientists in society as well as the impact of mass media regarding scientific issues such as was the occasion of the H1N1 pandemic. The sample of our study consisted of 97 Greek senior high school students whose answers in an open question were analyzed by means of Content Analysis. Their statements revealed that they have a utilitarian view of science and technology, though they express concerns regarding the way the scientific and technological achievements are used. They are sceptical towards scientists whom they believe
\end{abstract}


are defenders of certain economic interests, especially after the way scientists were presented through the media after the H1N1 pandemic. School science education has not succeeded in creating a clear picture of the scientific process as students do not understand that science progresses mostly through scientific disputes. In addition, the mass media promote such misconceptions.

Keywords: Public science communication, Students' attitudes, Mass media, Content analysis, Science and society 


\section{Introduction}

It was at the end of April 2009 in Mexico that the first incidents of the swine flu made their appearance, which gradually spread all over the world to such an extent that on June 11 of the same year WHO acknowledged it as a pandemic. First estimations spoke of a flu with severe symptoms which could even lead to death patients who were otherwise healthy. Therefore the making of a vaccine which would protect from the disease was imperative and as a result pharmaceutical industries started a race against time. When the vaccine was first launched in the markets, the Greek state policy makers decided on a massive vaccination of the Greek population; the Greek scientific community however appeared divided as different scientists juxtaposed their viewpoints as to how safe the vaccine was, but they also raised questions as to how dangerous the swine flu actually was, causing confusion to the general public who was daily bombarded by controversial information.

Hilgartner and Bosk (1988) argued that the more a subject is presented in the mass media the more the mass media influence the public opinion. Regarding the H1N1 pandemic, the scientific community was puzzled by the role the mass media played in informing and shaping the general consensus and finally came to the conclusion that the public opinion was enormously influenced by the mass media at the time (Iacob, 2011; Wagner-Egger et al., 2011; Wheaton et al., 2011).

The relation between scientists and news media has many viewpoints. There are scientists who consider that their exposure on mass media was vital in order to contribute to the scientific literacy (Kyvik, 2005) of the general public and others that believe they helped towards the formation of a "democratic society of knowledge" (Peters et al., 2008, p.205). However no research has been conducted to clearly show the perception of scientists and the scientific community as a whole in the eyes of general public under the circumstances that arose by the impact of the H1N1 pandemic. The aim of this research is to reveal Greek senior high school students' perceptions about the role of science and scientists in society as well as the impact of mass media to them regarding scientific issues such as was the occassion of the H1N1 pandemic.

\section{Sample and method of the research}

As target population of the research we selected Greek high school students in their final year of studies, as they are about to fulfil their school studies. According to the Greek act concerning the goals of the Greek educational system (ACT 135, v.B., 18-10-2001) students by completion of compulsory education plus high school must have formed a clear and positive image in relation to science and scientists accordingly. Although it would be ideal to get a representative sample from all over Greece, this was not possible due to its great cost. As a result, we were confined to a convenient sample with as many as possible: schools, private or public, from areas more or less privileged and students attending courses in all three direction of studies (technological, science and humanitarian). Specifically, participants of this research come from public schools from Athens (Byron, Paggrati, Kaisariani, Pallini, Paiania, Menidi, Gerakas, Psychico), but also from provincial parts of Greece, such as Kalamata, Filiatra, and 
rural areas of the greater part of Messinia. Students of 3 major private schools of Athens participated in this survey/research, too.

For the purpose of this research we constructed an instrument (questionnaire) consisting of three closed questions about student's gender, direction of studies and parents' educational background and one open-ended question, the answer to which we intended to subject to content analysis:

It is common practice for scientific news as well as information to be released on the mass media and a little time later to be altered or revoked, while prominent scientists are debating on TV about scientific issues. Do the above affect your way of thinking about science and scientists?

The research instrument was distributed during February and March of the school year 2009 2010. We chose this period for two reasons:

a) since July 2009 Greeks were constantly "bombarded" by the mass media about the H1N1 pandemic and if there should be a vaccination of all people or not. In this situation the different opinions among the scientific community may have created confusion to most of the people.

b) by the end of February and March most of the students have fulfilled the goals of the school curriculum. Therefore if we examine these students' perceptions we also get a picture of the way the school curriculum affects future citizens' views about scientists and the scientific community.

We originally distributed 121 questionnaires, but only 97 were handed in fully filled in. Therefore the corpus of data is comprised of the 97 students' answers to the open ended question.

About two thirds of the sample $[\mathrm{N}=61(62.8 \%)]$ were female students and the majority of them $[\mathrm{N}=42(43.3 \%)]$ attended the technological direction of studies, $36(37.1 \%)$ attended the direction of humanities and only 19 students (19.6\%) attended the direction of science.

The corpus of texts was analyzed on the basis of Content Analysis. In detail, the texts were analyzed following the principles of Quantitative and Qualitative Content Analysis, as they were stated by Holsti (1969), Berelson (1984), Weber (1990) and by French researchers (Grawitz, 2001; Mucchielli, 2006; Veron, 1981) (classical thematic analysis). As a unit of analysis we defined the "meaning unit" "the constellation of words or statements that relate to the same central meaning" (Graneheim \& Lundman, 2004, p.106) or "theme" as Lasswell, Merner and de Sola Pool used to name it (as cited in Zagkos, Kyridis, Golia, \& Vamvakidou, 2007).

For the coding process the coders relied on the latent content, which means that the coders have to rely on their subjective interpretations which "only increases the importance of making the case that the judgments of coders are intersubjective, that is, those judgments, while subjectively derived, are shared across coders, and the meaning therefore is also likely to reach out to readers of the research" (Potter \& Levine - Donnerstein, 1999, p. 266). 
The steps that we followed in order to carry out this content analysis were the following (Berg \& Veer, 1988; Weber, 1990):

- Definition of the categories. We chose to use "the grounded" or "emergent" process of category identification, therefore the "variables (categories) emerged from the message pool... we [the researcher] decided what variables (categories) are essential to the testing or hypotheses or research question" (Neuendrof, 2002, p.97). Therefore, students' answers were read through several times to obtain a sense of the whole so as to finally conclude to a set of categories and subcategories that were exhaustive and mutually exclusive (Krippendoorff, 1980).

- $\quad$ Testing of the coding on sample of the text. Once the categories were established, two coders (two biologists - the first two authors) proceeded to coding a sample of 6 students' answers to the open ended question comprising of 40 meaning units (30 meaning units are considered to be an adequate number for the pilot test of intercoder reliability (Lacy \& Riffe, 1996). Each coder had to identify the meaning units in students' narrative and to code each one by a number that corresponded to a category (or subcategory where such one existed).

- Assessment of accuracy or reliability. The coders entered the data in an IBM SPSS 19.00 data file and an interrater reliability analysis using the Kappa statistic was performed to determine consistency among raters. The Cohen's kappa was estimated to be $0.843(\mathrm{~N}=40$ meaning units), which is almost perfect according to Landis \& Koch (1977, p.165). After establishing the intercoder reliability we moved on to resolving the disputes among the coders in order to avoid biases and to improve the overall reliability.

- $\quad$ Coding of the whole sample. Coders worked on the whole sample.

- Assessment of the achieved reliability. After the completion of the coding process the achieved reliability was estimated again by means of Cohen's kappa $(\kappa)$. The interrater reliability was found to be Kappa $=0.843(p<0.001), 95 \%$ CI $(0.825,0.861)$.

- Testing of the content validity. A group of three experts (academic colleagues) judged the content validity of the categories that emerged from the texts (Berg \& Veer, 1988).

\section{Results}

After the content analysis of the students' texts, 765 meaning units were collected, that is 7,8 meaning units per text (student). These meaning units were coded according to five (5) thematic categories. Table 1 demonstrates the distribution of the meaning units in each thematic category. 
Table 1. Distribution of students' statements in each thematic category

\begin{tabular}{lcc}
\hline Thematic category & $\begin{array}{c}\text { Frequency } \\
(\mathrm{v})\end{array}$ & $\begin{array}{c}\text { Percentage } \\
(\%)\end{array}$ \\
\hline 1. Scientific disputes and public opinion & 261 & 34,1 \\
2. Science - technology and society & 192 & 25,1 \\
3. The social responsibility and the social identity of the & 162 & 21,2 \\
scientist & 80 & 10,5 \\
4. General consensus on political and social issues & 70 & 9,2 \\
5. The role of the media & 765 & 100,0 \\
\hline Total & & \\
\hline
\end{tabular}

Greater frequency of occurrence we recorded for those statements which fall into the thematic category related to the effect of scientific disputes in the participants' way of thinking. The next immediate category regarding the frequency of occurrence of meaning units was the one which concerns the relation of science-technology and society, and the third in frequency category was the one that concerned the social role of the scientist. The two remaining thematic categories were represented in a smaller frequency $10,5 \%$ for "the general consensus on political and social issues" and 9,2\% for "the role of the media".

\section{Analysis of thematic categories}

\section{Thematic category 1: Scientific disputes and public opinion}

It addresses the thematic category with the greatest frequency of references. There are very few who claim that scientific disputes as they are presented in mass media "do not affect their way of thinking" or they "are indifferent to them" or they see it in a positive way, while the vast majority state that "of course they are influenced" (11,5\% of references). Those who see positively these disputes among scientists in the media, believe that "iit is necessary that conflicting opinions exist", as well as "it is necessary for these viewpoints to be examined from every aspect concerning scientific issues from all parts" promoting in this way science, while different opinions could generate further research, or to help "new ideas to develop" $(23,4 \%)$.

However, the greatest part of reports in this category is negative $(65,1 \%)$ because for many, "the picture of two scientists on screen arguing stains their opinion of them" (Table 2). There are many who believe that "these conflicts are promoted systemically" rendering scientists "unreliable" and thus "creating a negative public image of science". In the end, through those conflicts "the meaning of science is lost" and "either instigated or not [scientific conflicts] make it impossible to form an opinion for the scientific achievements" and "intensify uncertainty" as confusion is caused since "even experts seems to be divided". 
Table 2. Examples of references placed under the thematic category Scientific disputes and public opinion

Conflicts cannot be caused due to conflicting scientific findings, but because of conflicting interests.

The picture of two scientists arguing on TV windows stains my opinion of them.

Discussions contribute in the shaping of an opinion related to the science.

\section{Thematic category 2: Science-technology and society}

One out of four meaning units concerned the new discoveries and the relation of sciencetechnology with society, showing a "massive interest in the new discoveries of science" which is now "boisterous" and "add to the improvement of the quality of life of man". Some are sceptical $(31,3 \%)$ and express mistrust in relation to the way they will be used as "the same discovery can be used either for a good or a bad purpose". Therefore they state that "science should be submitted to a moral criticism". "Should undertake its sociall responsibility" as "laymen don't know if a new discovery is dangerous this is the reason why they are mistrustful". According to the more critical: "achievements of science support capitalism", "incubate a multitude of dangers which have sounded the alarm terrorising modern man" and "science and scientists will destroy man".

However most of them $(68,8 \%)$ are positive towards scientific discoveries and they have a utilitarian perspective: "human beings have a much better life because of scientific advancement" which gives "hope for an upgraded standard of life" and they "improve modern life considerable compared to the past". They believe that "science is aiming to the quality of life", is "hauling against diseases" and "should serve common good"; "it is a means of facilitating the life of man".

It was clear that students tended to refer to discoveries in the fields of health and dieting, stating that "any discovery dealing with either of the two is good to be published for the information of the public" because they are "fields which refer to the whole world all around the world universally".

Table 3. Examples of reports included in the thematic category Science technology and society

Science should have moral limits and boundaries and not to promote the doctrine science for the sake of science.

Certain issues are concealed or even and distorted because of interests.

Science should serve disinterested aims and should stand beyond political expediencies.

Science serves the needs of common good.

Science improves the quality of life of man. 


\section{Thematic category 3: The social responsibility and the social identity of the scientist}

Through their statements the students gave an extended description of the role of scientists and in their majority expressed a negative attitude.

Some $(8,6 \%)$ tried to define what scientist means: "he who discovers" and "explores the world around him" always "in the name of science", "[scientists] are global personalities" and "intellectuals" that "serve knowledge". According to the students' views a scientist's purpose should lead to "information with certainty for every new scientific achievement" for they have "a multisided responsibility", "their opinions can mould the opinion and the personality of everyone" as "the influence they are exercising on ordinary people is exceptional for they function as experts" and "can persuade with their sayings on each of their subject".

Those who are positive towards scientists $(16,7 \%)$ say that "they are worthy delegates of science" and "fight against dilettantes", "they live for science endeavouring in pursue of truth" "they are interested in a perpetual improvement and progress of science with actions in accordance with the common interest". They stand out "for their free spirit" "they exercise their profession with responsibility and a sense of social conscience", "they try to improve the modus vivendi of men" and "facilitate daily routine putting aside their personal promotion".

Nonetheless, the majority of references in this section clearly indicates a negative attitude of students $(74,7 \%)$ who are sceptical as to "whether scientists carry out a research for the promotion of science or as to if it is the reward they are offered that they are after" "they are a bunch of people running after money" and "their own personal promotion" through science, "they serve financial and social trusts" therefore "in many cases scientists project facts as they are usually obliged to do by society", "they don't respect human nature", "they are not really interested in resolving scientific matters" and the most sceptical believe that scientists "will ultimately destroy man".

Table 4. Examples of references integrated to the thematic category The social responsibility and the social identity of the scientist

Positive role:

Scientists have a common goal to accommodate everyday life of people.

Negative role:

Those who appear on TV are scientists who have been paid from different companies to promote a product they are selling in a commercial market.

Scientists serve financial and political interests.

Scientific evolution of scientists constitutes now the aiming goal.

Scientists are mere pawns of financial and political interests.

\section{Thematic category 4: General consensus on political and social issues}

In this thematic category statements of participants were included, which were considered as general estimations not directly linked to the rest of the thematic categories related either to the 
function of the political system or to more general opinions. More specifically there are statements $(6,3 \%)$ which support the (scientific) conflicts for "they should exist in a democratic society as the Greek one" which considers "polyphony as its keystone". Conflicts can reflect "economical", "political" or "social interests".

Many statements $(18,8 \%)$ targeted to the preference of TV viewers for programmes they watch. Some "rarely watch TV" while those who do watch it "refuse to watch gossip talk shows and serials" and prefer "documentaries".

In the majority of statements $(75,0 \%)$ there are criticisms that stand out concerning the ordinary man, who "learns in the quick, easy and cheap", "they are not interested", they watch the developments arising "unruffled" because "they don't really wish to get involved" and "prefer to live in ignorance in relation to the field of sciences", "refusing to act". As a result "citizens don't acknowledge worthy scientists" and "a feeling of insecurity is established mostly among the people with no expertise". We do not know "what is essential or not" nor "what is beneficial or needless" since in the end "nothing essential goes down to ordinary people".

For most "there are subjects that they cannot comprehend" because they "don't perceive them in the same way", irrelevant of "the social class they belong to". Unfortunately "ordinary people follow faithfully what they are instructed to do" as "they lack knowledge for specific fields". Those who are really interested "they will read more on the topic they are interested in".

Finally they declare that "each one of the ordinary people has his own opinion" and "his thought and criticism is influenced by the environment he is surrounded by". Moreover citizens "should hold the opinions they feel are right" leaving out "human selfishness".

\section{Thematic category 5: The role of the media}

Some students $(25,7 \%)$ acknowledge the role of the mass media in information as important as "for the ordinary man direct information for scientific advancements stems from TV" and there are "prestigious programmes on $\mathrm{TV}$ which endeavour to contribute effectively to educating TV audiences" but most $(74,3 \%)$ are very sceptical of the role of media as they believe that the truth is distorted and expediencies are served by some who make use of "the enormous influence that mass media have in the moulding of each one's personality". The main goal of mass media, as they say, "is not to inform" but "for products and services to be sold at any means", this is why we should not "not adopt unguarded all that mass media project" as "they don't really communicate what is actually happening around us", but "project what is to the advantage of the interested parties".

They also hold the mass media and TV mostly, as responsible for the "shaping of a disadvantageous picture" for science which relates directly "with the prestige and the quality of discourses which take place in the media", especially in relation to "discoveries referring to health" and "dieting". 
Table 5. Examples of reports were attached to the thematic category The role of the media.

In the mass media era "powerful TV personas" in channels are trying to mesmerize the public using different means.

The mass media show scientists only when controversial issues are arising.

TV has contributed to the shaping of a negative attitude towards sciences.

There are many cases where medicines appear on the mass media targeting to the promotion of the interests of pharmaceutical industries.

No one believes that the conflict on TV is done for the citizens' information for a specific scientific matter.

What is shown on TV is fake.

Human kind is subjugated to TV.

\section{Discussion}

Greek students in high school's last grade - and therefore tomorrow's active citizens - believe that science and technology should function for the welfare of society towards the improvement of the quality of life. They have, that is, a utilitarian view. Many express their concern for the handling of scientific and technological achievements, adopting a judgemental attitude towards science and its achievements proportional with the one which was recorded in other developed countries (Anderson, 2006; Nakagawa, Yagi, \& Kato 2011; Sagan, 1995; Song \& Kim, 1999), which can be considered as positive if we accept science as a social product (Kyridis \& Chronopoulou, 2008). Opposed to this judgemental attitude towards science and scientists is recorded scientists' glorification by populations of under developed countries (Sjøberg, 2002; Turkmen, 2008).

Students that participated in our research seem considerably sceptical towards scientists and believe that they are miles apart from the model of a scientist who is fighting for the revelation of knowledge, the way school textbooks teach. Students focused a lot on the ethical personal characteristics of the scientists revealing a pervasive fear that scientists are unreliable and easily manipulated or dominated something also found in the perceptions of scientists among students from other countries (Basalla, 1976; Song \& Kim, 1999) as also among several texts of the western literature (Haynes, 2003).

Although "public engagement is considered important to build trust" (Avard, Grégoire, \& Jea, 2008, p.6) and this can be achieved through mass media, students don't seem to trust information received by mass media even the scientific ones. Scientists who expressed their different opinions as to the risks or not of the vaccine and the virus H1N1 itself, are perceived as defenders of different interests in the eyes of public. Scientists have lost their status and are confronted with caution. The 'model reader' that Greek secondary school science textbooks form and to whom is allocated a great part of the communication act's control (Koulaidis, Demopoulos, Sklaveniti \& Christidou, 2001) seems to not adopt the scientist's authority as it is presented in the textbooks. House of Lords Select Committee on Science and Technology, 2000) 


\section{Macrothink Institute ${ }^{\mathrm{TM}}$}

Students do not seem to comprehend that a contradictory or a non final scientific discourse is by its nature such and cannot be different, because science progresses mostly through disputes, contradictions and disagreements among scientists (Campbell, 1985; Friedman,Dunwoody, \& Rogers, 1999; Gilbert \& Mulkay, 1984; Latour \& Woolgar, 1979; Mazur, 1981Myers, 1990; Nisbet et al., 2002; Schackley \& Smithson, 1989; Stocking \& Holstein, 1993; Wynne, 1996). We can also sustain that the discourse, even the disputes among scientists constitutes an integral element of the procedure of the practice of science (Campbell, 1985). However, the public looks for concrete scientific results and uses of scientific findings that would improve everyone's daily routine and resolve their problems. In this specific version of science, doubt, disagreement, uncertainty, has no place, as everything scientific is the one and only indisputable 'truth' (Collins, 1987; Pinch, 1981).

\section{Educational implications and implications of research}

Eurobarometer research has shown that Greece compared to other European countries has lower school knowledge and engagement to activities regarding socio-scientific issues (Gaskell, Allansdottir, \& Allum, 2006). Given that every citizen in order to take decisions based on logical arguments should become familiar with scientific and technological concepts (Koulaidis et al., 2001) and that 'greater science literacy would ensure that the public makes "proper" risk judgments, that is, risk assessments in line with those of scientists or experts' (Nisbet, et al., 2002, p.591), we realise that we should focus on reforming science curricula in order to achieve the goals of scientific literacy (Christidou, 2011). Therefore, more research in the field of science curricula in Greece is needed.

The results of this and similar research could help on improving communication \& policy decisions about health issues by taking under consideration the public's views (Henrich \& Holmes, 2011) and improving the communication between research institutions and society.

\section{References}

ACT 135, v.B. (18-10-2001). article C, pp. 1199-1622 (in Greek).

Anderson, I.K. (2006). The Relevance of Science Education: As seen by Pupils in Ghanaian Junior Secondary Schools. Dissertation, University of the Western Cape, South Africa. Retrieved from http://roseproject.no/network/countries/ghana/gha-anderson-thesis.pdf

Avard, D., Grégoire, G., \& Jean, M.S. (2008). Involving the Public in Public Health Genomics: A Review of Guidelines and Policy Statements. GenEdit, 6(1), 1-9. Retrieved from http://www.humgen.org/int/GE/en/2008-1.pdf

Bauer, M.W. (2009). Comparative Evidence Discourse and the Evolution of Public Understanding of Science. Science, Technology \& Society, 14(2), 221-240. Retrieved from http://dx.doi.org/10.1177/097172180901400202.

Berelson, B. (1984). Content analysis in communication research. New York: Hafner. 
Berg, H., \& Veer, K. (1988). Semantic validity - Testing the operationalization of ideological frames of reference. Quality \& Quantity, 22(3), 311-330. Retrieved from http://hdl.handle.net/10.1007/BF00183543

Campbell, B. L. (1985). Uncertainty as symbolic action in disputes among experts. Social Studies of Science, 15(3), 429-453. Retrieved from http://dx.doi.org/10.1177/030631285015003002

Christidou, V. (2010). Greek students' images of scientific researchers. Journal of Science Communication, 9(3), A01. Retrieved from http://jcom.sissa.it/archive/09/03/Jcom0903\%282010\%29A01/Jcom0903\%282010\%29A01.p df

Christidou, V. (2011). Interest, attitudes and images related to science: Combining students' voices with the voices of school Science, teachers, and popular science. International Journal of Environmental \& Science Education, 6(2), 141-159. Retrieved from http://www.ijese.com/IJESE_v6n2_Vasilia_Christidou.pdf

Collins, H. M. (1987). Certainty and the public understanding of science: science on television. Social Studies of Science, 17(4), 689-713. Retrieved from http://dx.doi.org/10.1177/030631287017004005

Friedman, S. M., Dunwoody, S., \& Rogers, C. L. (eds.) (1999). Communicating Uncertainty: Media Coverage of New and Controversial Science. Mahwah, NJ: Erlbaum Press.

Gaskell, G., Allansdottir, A., Allum N., Corchero, C., Fischler, C., ...Wagner, W. (2006). Europeans and Biotechnology in 2005: Patterns and Trends - Eurobarometer 64.3. Funded by DG Research, European Commission Retrieved from http://www.rischio.unibo.it/wp-content/uploads/2010/09/OGM_eurobarometer.pdf

Gilbert, G. N., \& Mulkay, M. (1984). Opening Pandora's Box: A Sociological Analysis of Scientists Discourse. Cambridge, U.K.: Cambridge University Press.

Graneheim, U.H., \& Lundman, B. (2004). Qualitative content analysis in nursing research: concepts, procedures and measures to achieve trustworthiness. Nurse Education Today, 24(2), 105-112. Retrieved from http://dx.doi.org/10.1016/j.nedt.2003.10.001

Grawitz, M. (2001). Méthodes des sciences socials (11e éd.). Paris: Dalloz.

Haynes, R. (2003). From alchemy to artificial intelligence: Stereotypes of the scientist in Western literature. Public Understanding of Science, 12(3), 243-253. Retrieved from http://dx.doi.org/10.1177/0963662503123003

Henrich, H.N., \& Holmes, B. (2011). What the Public Was Saying about the H1N1 Vaccine: Perceptions and Issues Discussed in On-Line Comments during the 2009 H1N1 Pandemic. PLoS ONE, 6(4), e18479. Retrieved from http://dx.doi.org/10.1371/journal.pone.0018479 


\section{Macrothink}

Journal of Studies in Education

ISSN 2162-6952

2012, Vol. 2, No. 4

Hilgartner, S., \& Bosk, C.L. (1988). The rise and fall of social problems: A public arena model. American Journal of Sociology, 94(1), 53-78. Retrieved from http://www.unc.edu/ fbaum/teaching/PLSC_SOC_497_SP_2008/Hilgartner_Bosk_AJS_198 8.pdf

Holsti, O.R. (1969). Content Analysis for the Social Sciences and the Humanities. Reading, MA: Addison-Wesley.

House of Lords Select Committee on Science and Technology (2000). Science and society (3rd Report). London: HMSO. Retrieved from http://www.publications.parliament.uk/pa/ld199900/ldselect/ldsctech/38/3801.htm

Iacob, T. (2011). Mass-media impact on population's anxiety regarding A (H1N1) influenza. $\begin{array}{llll}\text { Mediciina Interna, } & \text { 2. } & \text { Retrieved }\end{array}$ http://www.medicina-interna.ro/articol.php?articol=651\&lang=en

Koulaidis, V., Demopoulos, K., Sklaveniti, S., \& Christidou, V. (2001). The Texts of Techno-Science in the Public domain. Athens: Metaixmio (in greek).

Krippendorff, K. (1980). Content analysis: an introduction to its methodology. Newbury Park: Sage Publications.

Kyridis, A. \& Chronopoulou, A. (2008). On scientific ethics and scientific practice. Athens: Gutenberg - George \& Kostas Dardanos (in Greek).

Kyvik, S. (2005). Popular Science Publishing and Contributions to Public Discourse among University Faculty. Science Communication, 26(3), 288-311. Retrieved from http://dx.doi.org/10.1177/1075547004273022

Lacy, S., \& Riffe, D. (1996). Sampling error and selecting intercoder reliability samples for nominal content categories: Sins of omission and commission in mass communication quantitative research. Journalism \& Mass Communication Quarterly, 73(4), 963-973. Retrieved from http://dx.doi.org/10.1177/107769909607300414

Landis, J., \& Koch, G.G. (1977). The measurement of observer agreement for categorical data. Biometrics, 33(1), 159-174.

Zagkos, Ch., Kyridis, A., Golia, P., \& Vamvakidou, I., (2007). Greek university students describe the role of Greece in Balkans: from equality to superiority. Nationalities Papers, 35(2), 341-367 (p.351).

Latour, B., \& Woolgar, S. (1979). Laboratory Life: The Social Construction of Scientific Facts. Beverly Hills, CA: Sage.

Mazur, A. (1981). The Dynamics of Technical Controversy. Washington, D.C.: Communications Press.

Mucchielli, R. (2006). L' analyse de contenu des documents et des communications. Paris: ESF. 


\section{Macrothink}

Journal of Studies in Education

ISSN 2162-6952

2012, Vol. 2, No. 4

Myers, G. (1990). Writing Biology: Texts in the Social Construction of Scientific Knowledge. Madison: University of Wisconsin Press.

Nakagawa, C., Yagi, E., \& Kato, K. (2011). What are the features of non-expert opinions on regenerative medicine? Opinion analysis of workshop participants. Journal of Science Communication, $10(2), \quad$ A02. $\quad$ Retrieved from http://jcom.sissa.it/archive/10/02/Jcom1002\%282011\%29A02/Jcom1002\%282011\%29A02.p df

Neuendorf, K.A. (2002). The content analysis guidebook. Thousand Oaks, California: Sage Publications, Inc.

Nisbet, M.C., Scheufele, D.A., Shanahan, J., Moy, P., Brossard, D., \& Lewenstein, B.V. (2002). Knowledge, reservations, or promise? A media effect model for public perceptions of science and technology. Communication Research, 29(5), 584-608. Retrieved from http://dx.doi.org/10.1177/009365002236196

Peters, H. P., Dominique, B., de Cheveigni, S., Dunwoody, S., Kallfass, M., Miller, S., \& Tsuchida, S. (2008). Interactions with the Mass Media. Science, 321, 204-205.

Pinch, T. (1981). The sun-set: the presentation of certainty in scientific life. Social Studies of Science, 11(1), 131-158. Retrieved from http://dx.doi.org/10.1177/030631278101100106

Potter, W. J., \& Levine - Donnerstein, D. (1999). Rethinking validity and reliability in content analysis. Journal of Applied Communication Research, 27(3), 258-284.

Sagan, C. (1995). The Demon Haunted World: science as a candle in the dark. New York: Random House.

Shackley, S., \& Wynne, B. (1996). Representing uncertainty in global climate change science and policy: boundary ordering devices and authority. Science, Technology and Human Values, 21(3), 275-302. Retrieved from http://dx.doi.org/10.1177/016224399602100302

Sjøberg, S. (2002). Science for the children? Report from the Science and Scientists-project (1/2002). Oslo: University of Oslo.

Smithson, M. (1989). Ignorance and Uncertainty: Emerging Paradigms. New York, Springer-Verlag.

Song, J., \& Kim, K.S. (1999). How Korean students see scientists: the images of the scientist. International Journal of Science Education, 21(9), 957-977. Retrieved from http://dx.doi.org/10.1080/095006999290255

Stocking, S. H., \& Holstein, L. W. (1993). Constructing and reconstructing scientific ignorance: ignorance claims in science and journalism. Science Communication, 15(3), 186-210. Retrieved from http://dx.doi.org/10.1177/107554709301500205

Turkmen, H. (2008). Turkish Primary Students' Perceptions about Scientist and What Factors Affecting the Image of the Scientists. Eurasia Journal of Mathematics, Science \& 
Technology Education,

$4(1)$ 2012, Vol. 2, No. 4

http://www.ejmste.com/v4n1/Eurasia_v4n1_Turkmen.pdf

Veron, E. (1981). Construire l'évènement: Les medias et l'accident de Three Mile Island. Paris: Editions de Minuit.

Wagner-Egger, P., Bangerter, A., Gilles, I., Green, E.G.T., Rigaud, D., Krings, F., Staerklé, C., \& Clémence, A. (2011). Lay perceptions of collectives at the outbreak of the H1N1 epidemic: heroes, villains and victims. Public Understanding of Science, 20(4), 461-476. Retrieved from http://dx.doi.org/10.1177/0963662510393605

Weber, R.P. (1990). Basic Content Analysis (2 ${ }^{\text {nd }}$ ed.). Newbury Park, California: Sage University Paper.

Wheaton, M.G., Abramowitz, J. S., Berman, N.C., Fabricant, L.E., \& Olatunji, B.O. (2011). Psychological Predictors of Anxiety in Response to the H1N1 (Swine Flu) Pandemic. Cognitive Therapy and Research, 36(3), 210-218. Retrieved from http://dx.doi.org/10.1007/s10608-011-9353-3 